\title{
EFFECT OF PRE-HARVEST POTASSIUM CHLORIDE TREATMENT ON ANTHRACNOSE DISEASE DEVELOPMENT IN HARVESTED TOMEJC MANGO (Mangifera indica L.) FRUITS
}

\author{
YMC Nisansala $^{1}$, LKRR Jayakody ${ }^{2 *}$, HA Sarananda ${ }^{3}$ and S Somaratne ${ }^{2}$ \\ ${ }^{1}$ Kalutara Study Centre, The Open University of Sri Lanka, Nagoda Road, Kalutara \\ ${ }^{2}$ Department of Botany, The Open University of Sri Lanka, Nawala, Nugegoda \\ ${ }^{3}$ Food Research Unit, Gannoruwa, Peradeniya, Sri Lanka
}

\begin{abstract}
Mango (Variety "TomEJC") has the highest potential in the export market due to its quality characteristics: excellent flavor, low fiber content and smooth flesh. However, the variety takes two weeks to ripen to table-ripe stage, after harvest. Due to this slow ripening nature of the variety, development of anthracnose has a high potential which leads to rejection by consumers. This disease can be effectively controlled with chemical treatments or fungicides, which may render the treated fruits less safe for consumption. This research was carried out to find out the effect of pre-harvest $\mathrm{KCl}$ application on the control of anthracnose development of ripe fruits. Three $\mathrm{KCl}$ concentrations, $1 \mathrm{~g} \mathrm{I}^{-1}, 2 \mathrm{~g} \mathrm{I}^{-1}$ and $4 \mathrm{~g} \mathrm{I}^{-1}$ were sprayed separately once on to fruits at immature (one-month after fruit set) at pre-harvest stage. Fruits harvested at the correct maturity were inoculated with Colletotrichum gloeosporioides spore suspension and allowed for natural ripening in a humid chamber. Incidence and severity of anthracnose disease was significantly lower on mangoes treated with $2 \mathrm{~g} \mathrm{l}^{-1} \mathrm{KCl}$ compared to other treatments and untreated control. Fruit length, fruit width, fruit volume and peel color did not affect by the treatments. Therefore $2 \mathrm{~g} \mathrm{I}^{-1} \mathrm{KCl}$ could be recommended as a pre-harvest application to mango fruits to minimize post-harvest incidences of anthracnose.
\end{abstract}

Key words: Colletotrichum gloeosporioides, anthracnose lesions, post-harvest losses, disease severity, disease incidence, potassium chloride

\section{INTRODUCTION}

"TomEJC" Mango (Mangifera indica L) is a beautiful golden orange fruit normally with an unblemished skin. It has an excellent flavor, low fiber content and smooth flesh. The fruit ripens slowly (takes two weeks to ripen to table ripe stage after harvest) giving time for the produce to reach the market (Wijesinghe et al., 2011). Among the promising mango varieties in Sri Lanka, "TomEJC" is considered the most suitable variety for the export market due to above characteristics. This variety is recommended to be grown in the dry (annual rainfall $<700 \mathrm{~mm}$ ) and intermediate zones of Sri Lanka

*Corresponding author: ramanijayakody@yahoo.com by the Department of Agriculture (www.tjcmango.com/tjc-mango).

This mango variety serves as a host for a number of pathogens among which fungi are the major agents of fruit rot after harvest (Sangeetha \& Rawal 2009). Botryodiplodia theobromae and Colletotrichum gloeosporioides are the two most prevalent disease causing agents that contribute significantly to postharvest losses of mango in Sri Lanka (Wijeratnam et al. 2008). The termination of fungal quiescence on mango is related to the reduction of anti-fungal compounds (Prusky, 1996) at ripening stage or the production of ethylene by the ripening fruit (Freeman et al., 
1998). The susceptibility of mango fruit to post -harvest diseases increase during storage after harvest, as a result of physiological changes and senescence favoring pathogen development (Prusky, 1996).

In the case of postharvest anthracnose, developing fruits are infected in the field but infections remain quiescent until the onset of repining, which occurs after harvest. Once the climacteric period of the fruit starts, lesions begin to develop (Arauz, 2000). Ripe fruits affected by anthracnose develop sunken, prominent, dark brown to black decay spots before or after picking. Fruits may drop from trees prematurely. The fruit spots can and usually do coalesce and can eventually penetrate deep into the fruit, resulting in extensive fruit rotting (Nelson, 2008).

Currently, the control of post-harvest diseases of mango fruit mostly depends on a combination of pre- and post-harvest fungicide treatments. However, increased consumer attention on health risks and environmental hazards associated with the use of pesticides (Wilson et al., 1994), the legislative restriction aimed at increased food security, the development of pathogen strains resistant to few permitted post -harvest fungicides and the need for high quality products, have promoted the search for alternative control measures to chemical fungicides (Sanzani et al., 2009).

Induction of host resistance is one strategy that holds promise for the control of post-harvest diseases (Adikaram, 1990). Recently, disease control by inducing host resistance and activating the defense mechanisms in plants (especially herbaceous plants) and harvested fresh produce (Johnson \& Hofman, 2009) have been reported.

The role of $\mathrm{K}$ in crop resistance to diseases was extensively reviewed by Perrenoud, (1990) and an inverse relationship was found between available soil $\mathrm{K}$ and the severity of diseases caused by bacteria and fungi (Huber \& Amy,
1985).

Potassium fertilizer such as mono potassium phosphate (MKP), applied as foliar sprays were highly effective inducers of systemic protection against powdery mildew in cucumber, mango, nectarines and grapes (Reuveni and Reuveni, 1995a \& 1995b). Further, high K levels of fertilizer have shown to reduce severity of anthracnose of banana and mango in Sri Lanka (Coates, 2002-2007).

Therefore, this study was carried out to find out the possibility of using $\mathrm{KCl}$ to reduce anthracnose development of "TomEJC" mango as a pre-harvest treatment.

\section{MATERIALS AND METHODS}

Mango variety, "TomEJC", was used in this experimental plot, at Ellawala farm, Galkiriyagama, Dambulla. Orchard management was done using standard agronomic practices recommended by the Department of Agriculture, Sri Lanka (http://www.doa.gov.lk/index.php/ en/crop recommendations/1087).

Three different concentrations of potassium chloride $(\mathrm{KCl})\left(1 \mathrm{~g} \mathrm{l}^{-1}, 2 \mathrm{~g} \mathrm{l}^{-1}\right.$ and $\left.4 \mathrm{~g} \mathrm{l}^{-1}\right)$ were sprayed on to selected mango fruits when they were at egg size (one month after fruit set). Each concentration was sprayed once to ten mango fruits in three different trees (ten mango fruits per plant per concentration) until the entire fruit was wet and the solution dripped off from the fruit (approximately $10 \mathrm{ml}$ ) using a hand sprayer. Twenty fruits on another tree, which were not sprayed with $\mathrm{KCl}$ were designated as control I and control II (control $\mathrm{I}=$ non -treated mango fruits which were inoculated with Colletotrichum gloeosporioides and control II = non-treated, non-inoculated mango fruits). Treatments in the field were done in a complete randomized block design. After spraying, all treated and control fruits were labeled and covered using special paper bags imported from Thailand. 
The fruits were harvested three months after bagging and brought into the laboratory at The Open University of Sri Lanka and experiments were carried out to examine the quality criteria, disease incidence/disease severity and the potassium content in the fruit peel.

\section{Quality criteria}

Quality criteria such as fruit size, fruit volume, total soluble solids and peel/flesh color of treated and non-treated fruits were measured after inoculation with $C$. gloeosporioides. Three fruits were used to measure the quality criteria, such as fruit size, fruit volume and total soluble solids and five fruits were used to measure the peel/flesh color.

\section{Fruit size}

Fruit length (from stalk end to the apex) and width (at the widest position) were measured using a Vernier caliper (Karemera and Habimana, 2014).

\section{Fruit volume}

Fruit volume was measured using water displacement method. Fruits were dipped in a water beaker and displaced water was collected and the volume was measured using a measuring cylinder. This volume was taken as the fruit volume (Saranada, unpublished data).

\section{Total soluble solids (TSS)}

A few drops of the filtrate of diluted juice (1 $\mathrm{ml}$ juice sample: $9 \mathrm{ml}$ distilled water) obtained from treated and control fruits were used to measure the TSS using a hand-held refractometer (model-HR-5 A022-1, Kyowa optical Co Ltd., Tokyo, Japan). The reading obtained was multiplied by the dilution factor (DF) to calculate the actual TSS content of the pulp $(\mathrm{DF}=$ weight of sample + volume of water added/weight of sample), expressed as Brix (Sarananda \& Wijerathnam, 1994).

\section{Peel color and flesh color}

Peel and flesh color measurements were done at the Institute of Post-harvest Technology,
Anuradhapura. Peel color and flesh color were measured objectively using a Minolta Chromameter (Minolta, Model CR-400, Osaka, Japan). Color attributes were expressed in terms of CIE (Commission International de L' Eclairage, International Commission on Illumination) three-dimensional color space and denoted as $L^{*}, a^{*}$ and $b^{*}$. The value $L^{*}$ is a measure of lightness (white-black and ranges from black $=0$ to white $=100)$; $\mathrm{a}^{*}$ ranges from negative values for green to positive values for red and the $b^{*}$ ranges from negative values for blue to positive values for yellow. $L^{*}, a^{*}$ and $b^{*}$ values were converted to hue $\left(\mathrm{h}^{0}\right)$ value and Chroma (C) (McGuire, 1992).

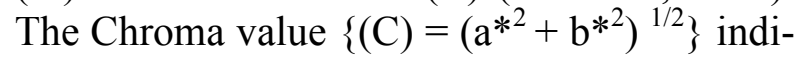
cates the strength of color. The hue value was measured as the hue angle. The hue angle $\left(\mathrm{h}^{0}=\operatorname{arctangent}\left(\mathrm{b}^{*} / \mathrm{a}^{*}\right)\right.$ of target color). The hue angle was expressed in degrees: $0=($ red $)$, $90^{\circ}=($ Yellow $) 180^{\circ}=($ green $), 270^{\circ}=($ blue $)$ (Jha, 2010).

\section{Disease incidence and severity of Anthrac- nose}

Anthracnose disease incidence and severity was assessed by artificial inoculation of fruits with C. gloeosporioides. A conidial suspension $\left(10^{5}\right.$ conidia per $\left.\mathrm{ml}\right)$ of the fungus was prepared using a pure culture and inoculated to the treated and control fruits (control I) as given below. Ten replicate fruits were used to assess the disease incidence and severity of Anthracnose.

Mango fruits were surface sterilized with $70 \%$ $\mathrm{v} / \mathrm{v}$ ethanol and washed with sterilized distilled water and air-dried in a lamina flow for half an hour. Then three holes were made (just below the stalk, mid position and above the apical end) using a sterilized cork borer (4 $\mathrm{mm}$ ) in each fruit (Adikaram, 1986-87; Zeng et al., 2006; Wijeratnam et al., 2008 ; Awa et al., 2012).

The inoculation was carried out after half an hour by placing $0.1 \mathrm{ml}$ of conidial suspension of C. gloeosporioides into each hole. Thereaf- 
ter, inoculated fruits were arranged randomly in a humid chamber covered with a glass $(28$ ${ }^{0} \mathrm{C}$ and $\left.100 \% \mathrm{RH}\right)$. Disease incidence was recorded daily and disease severity was assessed by measuring the lesion area $\left(\mathrm{mm}^{2}\right)$ of infected fruits by tracing the diseased area onto a tracing paper and then calculating the diseased area using a graph paper with $1 \mathrm{~mm}^{2}$ squares from $6^{\text {th }}$ day until $11^{\text {th }}$ day, after inoculation (Karunanayaka et al., 2011).

\section{The potassium content in fruit peel}

Determination of potassium content in the fruit peel was carried out at Horticultural Crop Research and Development Institute, Gannoruwa. The residual potassium content in fruit peel was measured using the dry ashing procedure. The concentration of potassium in the diluted solution was determined by the flame emission spectrophotometer using the method described by Senevirathna \& Daundasekera (2010).

Peels were obtained separately from three randomly selected fruits of each treatment and the controls. Each peel sample was air-dried and ground into a fine powder in a domestic grinder (Oster BY-TAR, U.S.A). Subsequent$1 y, 0.5 \mathrm{~g}$ of each ground sample was ashed in a muffle furnace (Lenton thermal designs, England) at $500{ }^{0} \mathrm{C}$ for 4 to 5 hours until ash turned white color. The powdery white dry ash residue obtained was wetted with $2.5 \mathrm{ml}$ concentrated nitric acid and volume was brought up to $25 \mathrm{ml}$ by adding de-ionized distilled water in a volumetric flask. The suspension was swirled for two minutes and filtered through Whatman No. $01(5.5 \mathrm{~cm}$ diameter $)$ filter paper to obtain digested (wet) samples. A dilution series of the sample solutions were prepared using the above $25 \mathrm{ml}$ sample solution. One (1.0) $\mathrm{ml}$ of each sample solution was transferred into volumetric flasks and the volume was brought up to $50 \mathrm{ml}$ by adding de -ionized distilled water. The residual potassium content of the peel was measured using the flame emission spectrophotometer
(Corning, CR 410) and was expressed as percentage potassium.

\section{Statistical analysis}

Data were analyzed using one-way analysis of variance (ANOVA) using SAS V. 9.2 (SAS, 2008), SPSS 16.0 (SPSS lnc., Chicago, IL, USA) to test the difference among treatments, considering all variables simultaneously and Tukey's Honest Significant Difference (HSD) Test to evaluate the level of effects for all pair-wise comparisons. Canonical Discriminate Analysis was used to represent the linear relationship of the colorimeter variables.

\section{RESULTS AND DISCUSSION}

\section{Effect of potassium on quality criteria of "TomEJC" mango}

Fruit length, fruit width and fruit volume were unaffected by treatments, compared to control fruits (Table 1). The highest TSS was observed in control II $(14 \pm 0.00)$ and a similar value was recorded in fruits treated with $4 \mathrm{~g}^{-1}$ $\mathrm{KCl}(13.75+0.08)$. The maximum level of $\mathrm{K}$ was observed in fruits treated with $4 \mathrm{~g}^{-1} \mathrm{KCl}$, which was $(0.61 \pm 0.01)$.

In the present study, $L^{*}$ values for peel color were not significantly affected by treatments (Table 2). According to the findings of this study, $b^{*}$ values were also not affected by treatments, indicating no change in yellowness. However, flesh color showed a different response to treatments. The highest lightness was observed in flesh of control II. A similar trend was observed with chroma. However, hue values for treatments and controls ranged between 82.90 and 79.74 and was not statistically significant (Table 2). Lowering of $b^{*}$ values for flesh color when compared to control II indicated a slight decrease in yellowness in flesh.

Effect of potassium on disease incidence and severity of anthracnose of "TomEJC" mango

The incidence of anthracnose disease in man- 
go fruits decreased gradually with increasing $\mathrm{KCl}$ concentration (Fig. 1). However, $1 \mathrm{~g} \mathrm{l}^{-1}$ $\mathrm{KCl}$ was less effective than the rest of the concentrations. Further, disease incidence was $40 \%$ lower in $1 \mathrm{~g} \mathrm{l}^{-1} \mathrm{KCl}$-treated fruits than the inoculated control (control I). Disease incidence was reduced to $50 \%$ and $70 \%$ in $2 \mathrm{~g} \mathrm{l}^{-1} \mathrm{KCl}$-treated fruits and $4 \mathrm{gl}^{-1} \mathrm{KCl}$ treated fruits, respectively (Figure 1). All concentrations of $\mathrm{KCl}$ were effective in decreasing anthracnose severity (Table 3 ). $\mathrm{KCl}$ treated fruits@ of $2 \mathrm{~g}^{-1}$ showed the lowest disease severity $(2.2 \pm 2.00)$ until day 9 from the time of inoculation (Table 3). Further, in $2 \mathrm{~g} \mathrm{l}^{-}$

${ }^{1} \mathrm{KCl}$-treated fruits, the lesion development was delayed until day 9. However, disease severity was higher in $2 \mathrm{~g} \mathrm{l}^{-1} \mathrm{KCl}$-treated fruits than $4 \mathrm{~g} \mathrm{l}^{-1} \mathrm{KCl}-$ fruits on day 10 and 11 (Table 3).

A considerable reduction in anthracnose disease incidence in mango fruits was evident with increased $\mathrm{KCl}$ concentrations. Similarly, a reduction in disease severity of mango fruits up to ripening level noted with increased $\mathrm{KCl}$ concentrations. One (1) $\mathrm{g} \mathrm{l}^{-1} \mathrm{KCl}$ was less ef-

\section{Table 1. Effect of KCl on quality of mango variety TomEJC}

\begin{tabular}{cccccc}
\hline Treatment & fruit length $(\mathbf{c m})$ & fruit width $(\mathbf{c m})$ & Fruit volume $\left(\mathbf{c m}^{3}\right)$ & $\begin{array}{c}\text { TSS } \\
(\text { Brix })\end{array}$ & K (\%) \\
\hline Control I & $14.52^{\mathrm{a}}(0.60)$ & $15.16^{\mathrm{a}}(6.65)$ & $464^{\mathrm{a}}(30.89)$ & $12.55^{\mathrm{b}}(0.59)$ & $0.41^{\mathrm{ab}}(0.00)$ \\
Control II & $15.50^{\mathrm{a}}(0.15)$ & $9.88^{\mathrm{a}}(0.08)$ & $505^{\mathrm{a}}(50.00)$ & $14.00^{\mathrm{a}}(0.00)$ & $0.54^{\mathrm{a}}(0.00)$ \\
$1 \mathrm{gl}^{-1}$ & $15.23^{\mathrm{a}}(0.33)$ & $9.28^{\mathrm{a}}(0.26)$ & $481^{\mathrm{a}}(59.92)$ & $12.25^{\mathrm{b}}(0.58)$ & $0.47^{\mathrm{b}}(0.00)$ \\
$2 \mathrm{gl}^{-1}$ & $15.47^{\mathrm{a}}(0.32)$ & $8.86^{\mathrm{a}}(0.37)$ & $504^{\mathrm{a}}(42.32)$ & $11.50^{\mathrm{b}}(0.00)$ & $0.54^{\mathrm{a}}(0.00)$ \\
$4 \mathrm{gl}^{-1}$ & $15.48^{\mathrm{a}}(0.64)$ & $8.88^{\mathrm{a}}(0.25)$ & $456^{\mathrm{a}}(24.24)$ & $13.75^{\mathrm{a}}(0.08)$ & $0.61^{\mathrm{b}}(0.01)$ \\
\hline
\end{tabular}

Mean $(\mathrm{n}=3) \pm$ Standard error

Values with the same letters in a column are not significantly different at ( $p \geq 0.05)$ by Tukey's Honest Significant Difference (HSD) Test. Control I = non-treated, inoculated Control II = non-treated ,non-inoculated and $1 \mathrm{~g} \mathrm{l}^{-1}, 2 \mathrm{~g} \mathrm{l}^{-1}, 4 \mathrm{~g} \mathrm{l}$

${ }^{-1} \mathrm{KCl}$ treated fruits.

Table 2. Effect of $\mathrm{KCl}$ on $\mathrm{L}^{*}, \mathrm{a}^{*}, \mathrm{~b}$ * values of peel and flesh color of mango variety TomEJC

\begin{tabular}{llllll}
\hline Treatment & $\mathbf{L}^{*}$ & $\mathbf{a}^{*}$ & $\mathbf{b}^{*}$ & Chroma & Hue \\
\hline Peel Color & & & & & \\
Control I & $49.84^{\mathrm{a}}(3.39)$ & $5.26^{\mathrm{b}}(0.68)$ & $31.41^{\mathrm{a}}(5.87)$ & $18.34^{\mathrm{a}}(2.93)$ & $76.53^{\mathrm{a}}(2.58)$ \\
Control II & $51.39^{\mathrm{a}}(2.04)$ & $7.50^{\mathrm{a}}(0.34)$ & $35.36^{\mathrm{a}}(3.11)$ & $21.43^{\mathrm{a}}(1.59)$ & $77.09^{\mathrm{a}}(1.52)$ \\
1gl-1 & $55.29^{\mathrm{a}}(2.78)$ & $4.56^{\mathrm{b}}(1.33)$ & $38.04^{\mathrm{a}}(4.60)$ & $21.30^{\mathrm{a}}(2.62)$ & $82.29^{\mathrm{a}}(2.21)$ \\
2gl-1 & $50.94^{\mathrm{a}}(2.73)$ & $3.76^{\mathrm{b}}(0.51)$ & $30.15^{\mathrm{a}}(4.43)$ & $16.95^{\mathrm{a}}(2.03)$ & $80.33^{\mathrm{a}}(2.23)$ \\
4gl-1 & $51.88^{\mathrm{a}}(3.27)$ & $5.49^{\mathrm{ab}}(0.46)$ & $33.80(5.10)$ & $19.65^{\mathrm{a}}(2.51)$ & $78.15^{\mathrm{a}}(2.40)$ \\
Flesh Color & & & & & \\
Control I & $60.01^{\mathrm{bc}}(2.58)$ & $8.42^{\mathrm{a}}(0.66)$ & $51.83^{\mathrm{c}}(3.44)$ & $30.13^{\mathrm{bc}}(1.92)$ & $80.69^{\mathrm{a}}(0.58)$ \\
Control II & $68.10^{\mathrm{a}}(0.83)$ & $8.98^{\mathrm{a}}(0.62)$ & $65.41^{\mathrm{a}}(0.76)$ & $37.20^{\mathrm{a}}(0.62)$ & $82.21^{\mathrm{a}}(0.47)$ \\
1gl-1 & $65.53^{\mathrm{ab}}(2.29)$ & $7.59^{\mathrm{a}}(1.60)$ & $61.51^{\mathrm{ab}}(3.04)$ & $34.55^{\mathrm{ab}}(1.83)$ & $82.90^{\mathrm{a}}(1.36)$ \\
2gl-1 & $60.27^{\mathrm{bc}}(3.56)$ & $6.87^{\mathrm{a}}(1.35)$ & $53.08^{\mathrm{bc}}(4.29)$ & $29.97^{\mathrm{bc}}(1.86)$ & $81.61^{\mathrm{a}}(1.86)$ \\
$4 \mathrm{gl}-1$ & $57.51^{\mathrm{c}}(3.01)$ & $8.82^{\mathrm{a}}(0.78)$ & $50.18^{\mathrm{c}}(3.76)$ & $29.50^{\mathrm{c}}(2.06)$ & $79.74^{\mathrm{a}}(0.90)$ \\
\hline
\end{tabular}

Mean $(n=5) \pm$ Standard error. Values with the same letters in a column are not significantly different at $(p \geq 0.05)$ by Tukey's Honest Significant Difference (HSD) Test. Control I= non-treated, inoculated Control II = non-treated, noninoculated, and $1 \mathrm{~g} \mathrm{l}-1,2 \mathrm{~g} \mathrm{l-1}, 4 \mathrm{~g} \mathrm{l-1} \mathrm{KCl}$ treated fruits. 
fective than the rest of the concentrations tested. The reduction of disease severity was more prominent from 6-8 days and it was not seen from day 9 to 11 . This may be due to the over ripening of fruits (Wijesinghe et al. 2011).

Numerous researches have shown that incidence and the rate of development of diseases may be reduced by an adequate and balanced mineral nutrition in many crops. In particular, $\mathrm{K}$ and $\mathrm{Cl}$ fertility have been effective in reducing crop injury from diseases (Magen and Imas, 2004). According to Marschner (1995), the benefit of $\mathrm{K}$ has been explained by its effect on primary metabolism by favoring the synthesis of high molecular weight compounds (protein, starch and cellulose), thereby decreasing the concentration of soluble sugars, organic acids, amino acids and amides in plant tissues, which are necessary for feeding pathogens and insects. These compounds are more prevalent in $\mathrm{K}$ deficient plants, which are more vulnerable to diseases and pest attacks. Further, there are reports on activation of K-dependent enzymes involved in energy metabolism, photosynthesis and solute transport and enzymes involved in sugar and nitrogen metabolism (Amtmann et al., 2008). These processes increase the ability of the plant to resist entry and infection by fungal, bacterial and viral pathogens and the beneficial effect of $\mathrm{K}$ was most obvious for fungal and bacterial diseases where $70-60 \%$ of studies reported a decrease in disease incidence (Amtmann et al. 2008). K dependence of starch synthesis (Nitsos \& Evans, 1969) and synthesis of pyruvate kinase (Smith et al. 2000) not only provide an explanation for the soluble sugar accumulation in K-deficient plants but also, this enzyme determines the rate of incorporation of carbon into starch or organic/amino acids, respectively (Amtmann et al. 2008). In studies of the influence of $\mathrm{K}$ on disease reduction, $\mathrm{Cl}$ has been shown to aid in the suppression of several plant diseas-

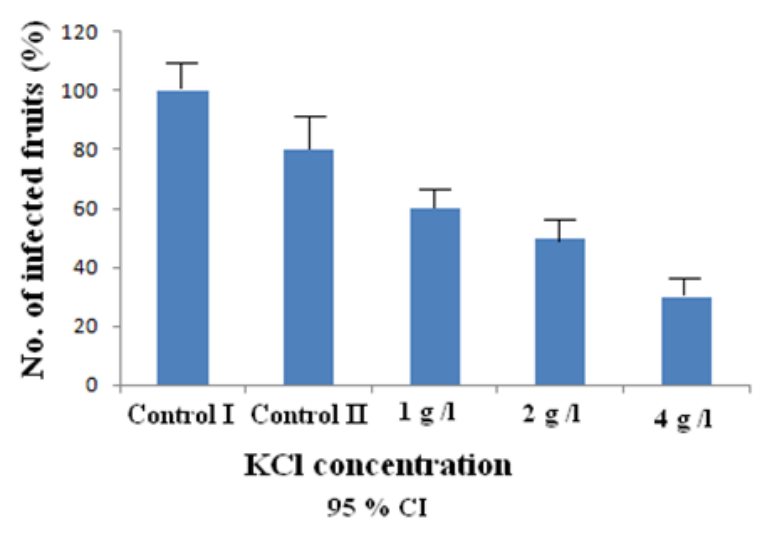

Control $\mathrm{I}=$ non-treated, inoculated

Control II = non-inoculated, non-treated

$1 \mathrm{~g} \mathrm{l}^{-1}=\mathrm{KCl}+$ inoculated

$2 \mathrm{~g} \mathrm{l}^{-1}=\mathrm{KCl}+$ inoculated

$4 \mathrm{~g} \mathrm{l}^{-1}=\mathrm{KCl}+$ inoculated

Figure 1. Effect of $\mathrm{KCl}$ on incidence of Anthracnose disease in mango variety TomEJC. Values are means of ten replicates at $95 \%$ confidence interval

Table 3. Effect of $\mathrm{KCl}$ on mean lesion area $(\mathrm{mm} 2)$ of Anthracnose disease (Colletotrichum gloeosporioides) of mango variety TomEJC.

\begin{tabular}{lcccccc}
\hline Trt & Day 06 & Day 07 & Day 08 & Day 09 & Day10 & Day 11 \\
\hline Control I & $12^{\mathrm{a}}(2.82)$ & $17.9^{\mathrm{a}}(2.81)$ & $27.5^{\mathrm{a}}(6.35)$ & $95.3^{\mathrm{a}}(54.79)$ & $106^{\mathrm{a}}(55.44)$ & $119.3^{\mathrm{a}}(54.12)$ \\
Control II & $5^{\mathrm{bc}}(1.67)$ & $11.8^{\mathrm{ab}}(3.58)$ & $21.7^{\mathrm{ab}}(6.35)$ & $26.8^{\mathrm{ab}}(6.96)$ & $34.3^{\mathrm{ab}}(8.88)$ & $44.1^{\mathrm{ab}}(10.95)$ \\
$1 \mathrm{gl}^{-1}$ & $6.4^{\mathrm{ab}}(2.71)$ & $17.9^{\mathrm{a}}(9.33)$ & $22.2^{\mathrm{ab}}(10.73)$ & $46.9^{\mathrm{ab}}(17.52)$ & $49.7^{\mathrm{ab}}(17.38)$ & $56.4^{\mathrm{ab}}(20.10)$ \\
$2 \mathrm{gl}^{-1}$ & $0^{\mathrm{c}}(0)$ & $0^{\mathrm{b}}(0)$ & $0^{\mathrm{c}}(0)$ & $2.2^{\mathrm{b}}(2.00)$ & $8.4^{\mathrm{b}}(3.73)$ & $29.41^{\mathrm{b}}(11.52)$ \\
$4 \mathrm{gl}^{-1}$ & $1.9^{\mathrm{bc}}(1.9)$ & $3.5^{\mathrm{b}}(2.81)$ & $4^{\mathrm{bc}}(2.92)$ & $5^{\mathrm{b}}(3.86)$ & $5.3^{\mathrm{b}}(3.93)$ & $9.6^{\mathrm{b}}(5.31)$ \\
\hline
\end{tabular}

Mean $(\mathrm{n}=10) \pm$ Standard error. Values with the same letters in a column are not significantly different at $(\mathrm{p} \geq 0.05)$ by Tukey's Honest Significant Difference (HSD) Test. Control I = non-treated, inoculated Control II = non-treated, non-

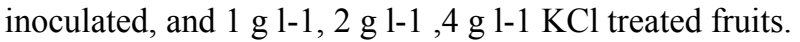


es (Huber and Amy, 1985). A recent study carried out by Rathnayake et al. (2010) have shown that application of $4 \% \mathrm{KCl}$ to fruits significantly reduced the Fusarium rot disease in papaya.

Different explanations on the possible ways of action of both $\mathrm{K}$ and $\mathrm{Cl}$ involved in the diverse diseases are presented and different mechanisms such as nutritional effects, changes of the host-pathogen environment and production of disease inhibitory compounds are discussed (Magen and Imas 2004).

The present data indicate that the pre-harvest application of $\mathrm{KCl}$ is effective in controlling anthracnose disease of "TomEJC" mango. The concentration of $2 \mathrm{~g} \mathrm{l}^{-1} \mathrm{KCl}$ was the most effective in reducing the anthracnose disease severity of variety TomEJC mango. The residual $\mathrm{K}$ level of $2 \mathrm{~g} \mathrm{l}^{-1} \mathrm{KCl}$ treated fruits was similar to that of untreated control showing that there is no residual effect. Further, there was no significant difference in sugar levels between treatments. The reduction in disease severity may be due to the production of antifungal compounds, which in turn increase the disease resistance of TomEJC mango and also delay the appearance of post-harvest disease symptoms. Karunanayaka et al. (2016) have reported that antifungal compounds were increased in the fruit peel of mango cultivar 'Karuthacolomban' by potassium silicate treatment which reduced the anthracnose development.

There was no significant difference in peel color parameters when compared to nontreated, inoculated control fruits (control I) indicating no significant effect of $\mathrm{KCl}$ treatment on the peel color. However, some significant differences were observed in some parameters of flesh color ( $\mathrm{L}^{*}, \mathrm{~b}^{*}$ and chroma) between $\mathrm{KCl}$-treated fruits and control fruits indicating a slight decrease in yellowness. In all treatments, hue value of flesh and peel of ripe fruits were close to $90^{\circ}$ which fall in the yellow quadrant. $\mathrm{KCl}$ treatments did not sig- nificantly affect the other parameters like fruit length, width and volume.

\section{CONCLUSION}

Preharvest application of $\mathrm{KCl}$ at a concentration of $2 \mathrm{~g} \mathrm{l}^{-1}$ on mango fruits resulted in relatively high control of anthracnose disease incidence and severity of "TomEJC". Further, the application of $\mathrm{KCl}$ at $2 \mathrm{~g}^{-1}$ on to fruits at preharvest stage resulted in no considerable variation in residual $\mathrm{K}$, compared to untreated control fruits and may not cause harmful effects on the consumer. $\mathrm{KCl}$ treatment does not have a significant effect on peel color, fruit length, width and fruit volume. Thus, preharvest $\mathrm{KCl}$ can be used as an alternative, safe treatment method in controlling anthracnose without affecting the appearance of fruits.

\section{ACKNOWLEDGEMENT}

Mr Tom Ellawala, Ellawala Farm, Dambulla, Mr MEMR Palipana, Institute of Post-harvest Technology, Anuradhapura and Staff at Food Research Unit, Gannoruwa, Peradeniya are gratefully acknowledged by the authors.

\section{REFERENCES}

Adikaram, NKB 1986-87 A Survey of postharvest losses in some fruits and vegetables and the fungi associated with them. Ceylon Journal of Science (Bio. Science) 19-20:110.

Adikaram NKB 1990 Possibility of control of post -harvest fungal diseases by manipulation of host defense system. Proceedings of the 3rd Conference on Plant Protection in the Tropics, Genting Highlands, Pahang. 5: 31-36.

Amtmann A, Troufflard S and Armengaud P 2008 The effect of potassium nutrition on pest and disease resistance in plants. Physiologia plantarum. 133: 682-691.

Arauz AL 2000 Mango Anthracnose: Economic impact and current options for integrated management. Plant disease. 84 (6): 600-611.

Awa OC, Samuel O, Oworu OO and Sosanya O 2012 First Report of Fruit Anthracnose in Mango caused by Colletotrichum gloeospori- 
oides in Southwestern Nigeria. International Journal of Scientific \& Technology Research. 1 (4): 30-34.

Coates L 2002-2007 Management of post-harvest diseases of sub-tropical and tropical fruits using their natural resistance mechanisms. Proceedings of research symposium on Postharvest handling of tropical fruits organized by Australian Center for International Agricultural Research (ACIAR).

Freeman S, Katan T and Shabi E 1998 Characterization of Colletotrichum species responsible for anthracnose diseases of various fruits. Plant Disease. 82: 596-605.

Huber DM and Amy DC 1985 Interaction of potassium with plant disease. pp. 467-488. In: Munson RD (ed.) Potassium in Agriculture. ASA/CSSA/SSSA, Madison, WI.

Jha AN 2010 Color measurement and modeling. pp. 17-40. In: Jha AN (ed.) Nondestructive evaluation of food quality: Theory and practice. Springer-verlag, berlin heidelberg.

Johnson GI and Hofman PJ 2009 Post-harvest technology and quarantine treatments. pp. 528-605. In: Litz RE (ed.) The Mango: Botany, Production and Uses. CABI.

Karemera NJU and Habimana S 2014 Influence of pre- harvest sprays of calcium chloride on post-harvest behavior of mango fruits, cv. Alphonso. International Journal of Social Sciences and Entrepreneurship Special Issue 2: 1-13.

Karunanayake LC, Adikaram NKB, Kumarihamy BMM, Bandara BMR and Abeysekara CL 2011 Role of antifungal gallotannins, resorcinols and chitinases in the constitutive defence of immature mango (Mangifera indica L.) against Colletotrichum gloeosporioides. J. Phytopathol. 159(10): 657-664.

Karunanayake LC, Sinniah GD, Adikaram NKB and Abeysekara CL 2016 Alternatives to synthetic fungicides in controlling postharvest anthracnose and stem-end rot in mango.Acta Hortic. 1144: 453-459.

Magen H and Imas P 2004 Potassium chloride and suppression of diseases. Poster presented at the XVTH International Plant Protection Congress, Beijing, China.

Mango 2006 Available online at: http:// www.doa.gov.lk/index.php/en/croprecommendations/1087. (accessed on 25th February 2016).
Marschner H 1995 Mineral nutrition of higher plants. Academic press, London.

McGuire RG 1992 Reporting of objective color measurements. Hort. Science. 27(12): 12541255.

Nelson SC 2008 Mango Anthracnose (Colletotrichum gloeosporioides). PD-48 .In: Plant Disease. College of tropical agriculture and human resources. Department of Plant and Environmental Protection Sciences. University of Hawaii at Manoa,

Nitsos RE and Evans HJ 1969 Effect of univalent cations on the activity of particulate starch synthetase. Plant Physiology. 44: 1260-1266.

Perrenoud S 1990 Potassium and plant health. 2Nd ed., IPI Research Topics 3. International Potash Institute, Basel, Switzerland.

Prusky D 1996 Pathogen quiescence in postharvest diseases. Annual Review of Phytopathology 34: 413-434.

Rathnayake RPSH, Sarananda KH and Abesekara CP 2010 Effect of potassium $(\mathrm{KCl})$ application on postharvest disease condition and fruit quality of ripe papaya (Carica papaya L.). Proceedings of Uva Wellassa University Annual Research Symposium, Sri Lanka, 63.

Reuveni M and Reuveni R 1995a Efficacy of foliar application of phosphates in controlling powdery mildew fungus on field-grown winegrapes: effects on cluster yield and peroxidase activity in berries. J. of Phytopathology . 143: 21-25.

Reuveni M and Reuveni R 1995b Efficacy of foliar sprays of phosphates in controlling powdery mildews in field-grown nectarine, mango trees and grapevines. Crop Protection. 14: 311-314.

Sangeetha CG and Rawal RD 2009 Temperature requirement of different isolates of Colletotrichum gloeosporioides isolated from Mango. American-Eurasian Journal of Scienctific Resources . 4(1): $20-25$.

Sanzani SM, Nigro F, Mari M and Ippolito A 2009 Innovations in the control of postharvest diseases of fresh fruit and vegetables. Arab Journal of Plant Protection. 27: 240244.

Sarananda KH and Wijerathnam RSW 1994 Controlled atmosphere storage of Embul banana. Tropical Agricultural Research. 6: 17-22. 
Senevirathna PAWANK and Daundasekera WAM 2010 Effect of post-harvest calcium chloride vacuum infiltration on the shelf life and quality of tomato (cv. 'Thilina'). Ceylon Journal of Science (Bio. Sci.). 39(1): 35-44.

Smith CR, Knowles VL and Plaxton WC 2000 Purification and characterization of cytosolic pyruvate kinase from Brassica napus (rapeseed) suspension cell cultures. European Journal of Biochemistry. 267: 4477-4485.

Wijeratnam SW, Darmatilaka Y and Weerasingha D 2008 Host specificity of Colletotrichum gloeosporioides and Botriyodiplodia theobromae isolates from mango, papaya, and rambutan and their responses to Trichoderma harzianum. Proceedings of Conference on International Research on Food Security, Natural Resource Management and Rural Development, Tropentag.
Wijesinghe MARN, Sarananda KH and Mendis BEP 2011 The Effect of pre -harvest application of potassium on fruit quality of "TJC" mango (Mangifera indica L.) selected for processing. Proceedings of University of Peradeniya Research Sessions, Sri Lanka.

Wilson CL, El-Ghaouth A, Chalutz E, Dorby S, Steven C, Lu JY, Khan V and Arul J 1994 Potential of induced resistance to control post -harvest diseases of fruit and vegetables. Plant Disease. 78: 837-844.

Zeng KF, Cao JK and Jiang WB 2006 Enhancing disease resistance in mango (Mangifera indica L. Cv. 'Matisu') fruit by salicylic acid. Journal of science of Food and agriculture. 86(5): 694-698. 